How to cite

Hussain, R. M. R., \& Al Saaidi, K. K. (2019). Students as designers of E-book for authentic assessment. Malaysian Journal of Learning and Instruction, 16(1), 23-48.

\title{
STUDENTS AS DESIGNERS OF E-BOOK FOR AUTHENTIC ASSESSMENT
}

\author{
${ }^{1}$ Raja Maznah Raja Hussain \& Khalid Khamis Al Saadi \\ Department of Instructional learning and Technologies \\ Sultan Qaboos University, Muscat, Sultanate of Oman
}

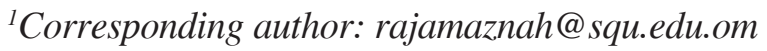

Received: 17 November 2018 Revised: 4 February 2019 Accepted: 7 March 2019

\begin{abstract}
Purpose - The purpose of this study is to examine the elements that determine students' success as designers of an e-book by means of an authentic assessment in a collaborative learning environment. A total of 11 English Language Teaching (ELT) postgraduate students were involved as designers, writers and peer reviewers of the e-book project.
\end{abstract}

Methodology - Data was gathered based on a qualitative methodological approach, via face-to-face discussions, WhatsApp groups, Moodle classes and reflections from students' e-portfolios. The data was analyzed using content analysis procedures where it was read carefully to understand emerging themes. It was then coded and labeled manually in relation to the aims of the study and its theoretical framework.

Findings - The analysis suggested that the students had positive experiences where they became self-publishers while engaged in designing learning experiences via integrating technology. The use of authentic assessments enabled them to develop teamwork, to become motivated and self-directed learners with autonomy.

Significance - The outcome of this research will help course designers and program developers to integrate authentic assessments that are relevant to the current needs of students. 
Keywords: Authentic assessment, design thinking, e-book design, technology enhanced learning.

\section{INTRODUCTION}

Research has indicated high expectations of university graduates when joining the job market in terms of matching knowledge learned to the real world (James \& Casidy, 2018; Oliver, 2015; Tout, Pancini, \& Mccormack 2014; Reid \& Fitzgerald, 2011). As a result, higher education institutions have paid greater attention toward reforming and altering the present practices of assessment (Crocker, 2013) in a way to encourage learners to utilize the knowledge gained to question, discuss and solve real world problems (Kinay $\&$ Bagceci, 2016). An outcome of this reform has resulted in the development of the concept of authentic assessment as a way forward to evaluate learners' understanding of what is taught to them and how to apply knowledge gained in the real world. By definition, authentic assessment is "the mirroring of real-world tasks or expectations" (Frey, Schmitt, \& Allen, 2012, p.1). This form of assessment is deemed to have the capabilities to improve students' learning and to prepare them for a changing world. Besides, it has been identified to equip learners with the skills that they need to meet present and future professional demands (Boud \& Soler, 2016). However, authentic assessment is only considered to be authentic when it is designed for real value (Thuy \& Dall'Alba, 2014). It allows instructors to determine whether their students have gained the knowledge and skills that allow them to be successful in the real world based on their abilities (James \& Casidy, 2018). Regardless of its exceptional popularity in higher education worldwide, there are still misconceptions regarding the meaning and application of authentic assessment among educators (Frey, Schmidt \& Allen, 2012). It needs to be more meaningful (Mueller, 2011) where students can act as participant designers in the creation and implementation of such assessments.

\section{Research Framework}

The theoretical framework of this study is based on social constructivism. This theory asserts that adults learn by constructing meaning from their experiences and that learners' active engagement 
during studying creates wide and flexible learning environments (Vygotsky, 1978). In order for learning to take place, learners need to be involved in the learning process (Estepp, Roberts, \& Carter, 2012) where they learn through their personal experiences. The role of educators is to provide learners with multiple opportunities to acquire knowledge (Patton, Parker, \& Neutzling, 2012). Students in this study were afforded many opportunities during the e-book project to collaborate, participate in discussions, share experiences, and reflect.

Research in education has shown that adults successfully learn through experience (Caulfield \& Woods, 2013). Experiential learning is an ideal approach to achieving the tenets of empowering education, because the results of direct experience are often concrete, easily identifiable and applicable. Students can identify the change they have created through experiential learning, which often leads to an increased sense of engagement and motivation (Perrin, 2014) as well as confidence. According to Kolb and Kolb (2005), experiential learning is the creation of knowledge through the conversion of our experiences. Concrete experience and abstract conceptualization assist in grasping experiences, while reflective observation and active experimentation transform these experiences (Kolb \& Kolb, 2005). Experiential learning results in positive outcomes due to students taking an active role in their own learning (McCarthy, 2010). Students in the e-book project were teachers who had previous experiences that could assist them in developing the project independently.

Research also suggests that reflective learning allows students not only to develop critical thinking skills, but also to foster selfawareness of their own learning and to develop abilities to selfregulate. Hadwin (2008) defined self-regulation as "the deliberate planning, monitoring and regulating of cognitive, behavioral and affective or motivational processes towards completion of an academic task" (p. 179). Students in this project engaged in reflective learning by stepping back from their learning and analyzed their experiences. Through reflection, the students were able to transform their experiences into knowledge which assisted in their learning. Learners develop the ability to integrate insights they have gained into their learning/life experience so that they can make better choices and improve their learning through reflection (Rogers, 
2001). During the e-book project, students wrote their reflections in their e-portfolios. The e-portfolio is designed to enhance student learning and growth through the use of self-reflection, integration, meta-cognitive appraisal of the learning process, and mentoring (Zubizaretta, 2009).

\section{LITERATURE REVIEW}

Young (1995) shared a view that knowledge is a product of the activity, context and culture in which it is developed and used, and must be evaluated as such assessment can no longer be viewed as an add-on to an instructional design or simply as separate stages in a linear process of pretest, instruction, and post-test. Rather, assessment must become an integrated, ongoing and seamless part of the learning environment. It has to be designed and implemented in accordance with teaching strategies (Darma, Candiasa, Sadia, \& Dantes, 2018). Assessment must not only be integrated with instruction but must focus on the learning process as well as the learning products (Case, 2015). Authentic assessments are assignments that ask students to answer essential questions in specific disciplines and use concepts as professionals in the field would. They focus on students using and applying knowledge and skills in real-life settings (Holliday et al., 2015). It helps students to contextualize their learning and to see how real-life conditions or situations, in all their unpredictability, ambiguity and complexity, affect their theoretical knowledge (UNSW Teaching, 2017). Svinicki (2004) suggested that authentic assignments should be based on student activities that replicate real world performances as closely as possible. This will increase their ability to think and problem-solve in ways that teachers think and act (Azim \& Khan, 2012).

According to Frey, Schmidt and Allen (2012), assignments are and can only be authentic when they meaningfully connect with students beyond the assigned grade at the end of their obligatory participation in the project. Frey, Schmidt and Allen (2012) in their research on "Defining authentic classroom assessment" concluded that the type of assessment experience that is truly authentic as "assessment task that involves the student deeply, both in terms of cognitive complexity and intrinsic interest, and are meant to develop or evaluate skills and abilities that have value beyond the assessment 
itself" (p. 14). The e-book project in this study allowed the students to explore mobile technologies and applications that support English language teachers to teach specific language skills. The e-book was written with the goal to benefit teachers and connect them beyond the course. It was eventually published and made available to other teachers and the community.

One of the expected outcomes of the e-book project was for students to develop independence and to be self-directed through authentic assessment. English and Kitsantas (2013) defined selfdirected learning as students taking part in learning that they specify, rather than defined by instructors. Authentic assessment allows individuals to take charge of planning, implementing and evaluating results (Hiemstra, 2011). These skills include setting learning goals, assessing whether the learning goals are met, and re-planning based on the assessment (Robertson, 2011; Zaibon \& Shiratuddin 2010). Learners who become self-directed continue their learning and become lifelong learners (Sibthorp et al., 2011). Students were given full autonomy in this e-book project to plan and to take full responsibility for the success of the project. It has been hypothesized that autonomous learning involves the application of personal initiative in engaging with learning and finding resources and opportunities for learning, persistence in learning, and resourcefulness (Ponton, Carr, \& Confessore 2000). Foo and Hussain (2010) reported in their study, that there is a learning curve associated with self-directed learning through authentic assessment. Initially, students will struggle to make the transition to self-directed learning. However, scaffolding and coaching in a project-based learning environment can promote self-regulated and self-directed learning. Project-based learning activities could also provide students opportunities to be personally coached and monitored by the instructor while indulging in peer-assisted learning through peer observation and peer assessment (Fauzi \& Hussain, 2016; Webb \& Moallem, 2016).

In recent years, interest in design thinking has grown among educators as it is a natural complement to inquiry, project-based learning, collaboration, and problem-solving. Teachers are increasingly being trained in how to use design thinking as a means to promote student creativity and problem-solving (Gallagher $\&$ Thordarson, 2018). Brown (2008) defines design thinking as a 
discipline that uses the designer's sensibility and methods to match people's needs with what is technologically feasible and what viable strategies can be converted into customer value and market opportunity. Hence, the researchers believed that the Sultan Qaboos University (SQU) students had the potential to grow and become independent learners. The researchers also believed that they could act as participant designers in the creation and implementation of an authentic assessment. These beliefs should influence the practice of supporting the students to engage with technology and inquiry, driving them to "personalize" their learning. Personalized learning has the purpose of encouraging students to become more involved in making decisions about what and how they want to learn (Campbell, Robinson, Neelands, Hewston, \& Massoli, 2007). Students also need to engage with project-based learning and handson learning allowing them to develop the skills of communication and collaboration while engaging in critical thinking and problemsolving in creative learning environments. These skills are valued as 21st century skills of which all graduates are expected to secure. Students also need to be encouraged to make choices and to make their voices heard in order to coexist and co-contribute to the learning community. All of these can be taken into account when instructors put pedagogy first, focusing on their teaching practice (Glover, Hepplestone, Parkin, Rodger, \& Irwin, 2016). The problem presented to the students in this research was to design an e-book to support the learning of English language teachers using technology for teaching and learning. They were introduced to design thinking at the inception of the project to help them think and produce viable solutions to the problem. The purpose of this study was to examine elements that determine the students' success as designers of an e-book, to serve as authentic assessment in a collaborative learning environment.

\section{The Current Study}

This study took place at the College of Education (COE) in Sultan Qaboos University (SQU) in the Sultanate of Oman where there has been increasing pressure by the accreditation Unit for the improvement of assessment tools and approaches in the college. Therefore, an assessment unit was established in 2013 as part of an ongoing accreditation process of the college. One of the main tasks of the assessment unit is to enhance the instructional and learning 
processes of the college academic staff through workshops to assist them in revising, improving and administering their assessment tools and approaches. However, the current assessment practice is still quite traditional as most of the academic staff are still using pen-andpaper assessments such as true/false, short answers, completion and multiple choice questions. Authentic assessment is rarely employed and only a few courses ask students to do assignments related to real school work. Many educators have no experience in designing authentic assessments and are often ill-prepared to implement them in their courses. Professional development workshops provided by the College failed to offer the educators with concrete and successful examples that can allow their students to become real learners capable of solving real world problems. Students should be presented with collaborative tasks that can enhance and develop their knowledge, skills and practice in a way that serves their future jobs (James \& Casidy, 2018).

The purpose of this study is to understand what elements enabled a selected group of postgraduate students at SQU to design and develop an e-book via a project to serve as authentic assessment in a collaborative learning environment. This paper in particular aims to answer the question: What elements enabled a selected group of postgraduate students at a public university in Oman to design and develop an e-book project successfully through authentic assessment in a collaborative learning environment? Since only a few studies in Oman have highlighted the issue of authentic assessment, it is hoped that this research could encourage the higher education faculty to adopt authentic assessment and employ real world tasks in courses that they teach. This study contributes to the literature of authentic assessment and technology integration as it provides insights to SQU academics on how technology can be utilized to engage students in the assessment process in a way to enhance their learning through the design and development of real tasks.

\section{METHODOLOGY}

\section{Choice of Research Method}

A qualitative case-study methodology was used in this study to examine what determined the students' success in collaboratively 
developing an e-book project. The researchers looked at factors which affected student learning to design and develop the e-book from a qualitative perspective. Case study research allowed the researchers to study the problem in depth and in the setting where it occurred (Sangster-Gormley, 2013). Qualitative research yields narrative data and is inductive. Case study research worked for this study because data was collected from the students to find meaning in the process of designing and developing an e-book through narrative descriptions.

\section{Study Design}

A course was designed to engage English language teachers (enrolled as postgraduate students) with emerging technologies to explore strategies to engage and support student learning in technology enhanced learning environments. This course was designed and taught before by other instructors. As scholar teachers, the researchers were always looking for new ways to facilitate our students' learning so as to engage them with the course content. The researchers reflected, "What if there was a better way to teach this course?" In accordance with the Scholarship of Teaching and Learning (SoTL) researchers (Boyer, 1990), the researchers redesigned the course to resonate with one of Hutching's (2002) taxonomy of questions (What if...) exploring the possibility of not only new teaching and learning practices, but also of new teaching and learning goals. The researchers collected evidence from our teaching and our students' learning which in turn gave us feedback on our practice and informed us of where our teaching was effective to our students.

The e-book project required the students to write about 21 st century skills and to suggest strategies and tools to develop chosen skills through personalized learning with the support of technology. The idea was to support other English language teachers to integrate technology in their practice. The project was a culmination of our face-to-face and online discussions, readings, WhatsApp group sharing and weeks of exploring technology and tools to enhance the teaching of English to students in schools and higher education institutions. The researchers thought that it would be beneficial for others to know what they, the researchers have learned in the course and that an e-book would be a good way to share our experiences 
and at the same time to support other teachers. Two cohorts had completed the course. The first cohort was given four weeks before the end of the semester to complete the e-book assignment project. Based on the first group's experience, the e-book assignment was offered to the second cohort as a semester long project of 14 weeks. This writing shares the learning from the second group as it enabled us to plan the research carefully and to document the experiences through observations, field notes, reflections and the students' selfappraisal.

\section{Participants}

The participants were 11 ELT teachers who registered for the course. Their experience in English Language Teaching (ELT) ranged from two to 14 years. The majority of them have used technology for personal and professional purposes. They were eager to learn more about new and emerging technologies. One of the students had more experience with technology tools and had a personal business in computer and designing. He was a method trainer in a specialized centre for professional training of English language teachers. With his expertise and experience, he agreed to lead the project and took on the role of Project Manager. Each teacher kept an e-portfolio as a tool for reflection where they wrote about their learning, thus making their voices heard. The researchers were able to use their writing to gauge the interest and ability of the students to engage with the technology and to process their learning. They were also engaged in a design project, where they designed an instruction for specific learning outcomes. The teachers chose to reflect on topics related to how technology can be used in transformative ways. These include Koehler and Mishra's (2009), "Technological Pedagogical Content Knowledge" (TPACK) model, Puentendura's (2010) "Substitution Augmentation Modification Redefinition" (SAMR) model and technology for flipped classroom.

\section{Design of e-book}

The project went through four stages: planning, editing, designing and; publishing. The planning stage involved: (1) selecting the topic for the e-book, (2) identifying the purpose and the audience, and (3) setting up a writing guideline. Planning was done in class with full participation from the students and instructors as a group 
brainstorming activity. The students were introduced to the e-book written by the first cohort. Their first task was to review the book and to give opinions on how to make the e-book better. The students were able to voice their opinions and suggestions and negotiated topics for their group's e-book project, the guidelines and timeline and even the publishing platform. Upon agreeing on the guidelines, the students started writing their chapters. The students selected their topic based on their interest. The editing stage included: (1) reviewing the chapters, (2) checking the originality of work with Turnitin, (3) checking and aligning the consistency of chapters, and (3) language editing. In this stage, the writers reviewed each other's chapter(s) and feedback on the contents was sent back to the writers to modify.

\section{Data Collection}

Initial data was collected from students' writing about their teaching experience and technology used in teaching and their course expectations. Second data source was from the students' reflections in the e-portfolio and their discussions in the WhatsApp group throughout the semester. The third source of data was from the selfappraisal, a guided reflection on the students' learning process of designing and developing the e-book which was collected at the end of the semester. The fourth data source was our weekly reflections and field notes. Generally, the students were asked many different questions to reflect or discuss in class and in the WhatsApp group to gain a deeper understanding about their experiences and roles in the design of the e-book project. Examples of these questions were: What were your roles in the design of the e-book project? What e-book design processes were the most valuable for you? What did you learn about the e-book design process from participating in the project? What did you need to learn more about in doing the e-book project? What did you have more experience with in doing the e-book project? How would you use this process in designing future e-book projects?

\section{Data Analysis}

Data analysis was an ongoing procedure. After the data was gathered from reflections, field notes and self-appraisal, it was analyzed using content analysis procedures. At first, all data sources were read and re-read carefully to gain an overall understanding of its contents. 
Then, it was coded using the open coding (Neuman, 2011; Merriam, 2009) process where units of meaning were identified, isolated into segments and then categorised under themes and categories in relation to the aim and theoretical framework of the study. These categories included: empowerment, teamwork and motivation, student behavior and productivity of instructors. A reflection journal was kept to note any biases that the researchers might have during the process.

\section{FINDINGS AND DISCUSSION}

Five themes emerged from the data. These are important elements or components of authentic assessment where the students or participants were engaged and empowered in a collaborative personalized learning environment. The first theme is related to the issue of student empowerment and student autonomy. The second theme is concerned with shared responsibilities and teamwork and the third theme is on motivation leading to lifelong learning. The fourth one is about promoting student behavior and the last one is regarding the productivity of instructors.

\section{1) Student empowerment and student autonomy}

The self-appraisal, reflective journals and conversations with students, revealed the importance of their involvement from the inception of the project to its completion. Even though initially, they seemed disorganized, full of uncertainty and voiced their difficulty in finding topics to write and the technology to write about for their specific chapters. Eventually, they found their goals and roles for each chapter and took it upon themselves to divide the tasks. They reported an increased sense of independence in directing their own project as they went through the steps of designing, developing and writing chapters for the e-book.

It's not an easy task. The content is the most important part. You can win or lose readers based on the content provided. Other elements like illustrations/ images/ colors can play a vital role in attracting readers.

- Student \# 7, discussing the e-book design process. 
The selection of the apps was a bit of a challenge for me. There are plenty of grammar apps in Google Play. I had to download as many as possible in my device and test their quality and usefulness by myself. I also appreciate all the moments of discussion in the classroom about the book.

\footnotetext{
- Student \# 9, discussing the e-book design process.
}

Learner autonomy occurs when students demonstrate persistence in finding resources and opportunities for learning (Ponton, Carr, \& Confessore, 2000). Students identified their own problems and found the solutions with very little guidance from the instructor. They were empowered to challenge their own understanding of concepts and the structure of the e-book design and publishing.

The development stage was the most valuable process for me. This stage involved many things that added to my knowledge. For example, I started by surfing the app stores to look for the most relevant and beneficial apps related to teachers' PD (professional development). Then I began to review literature in order to write a comprehensive introduction. In addition, I started to select the apps and developed short descriptions about them. So this stage was important to me and I learned many things

- $\quad$ Student \# 1, discussing the most valuable process in the e-book design.

Today, the group discussed possible titles for the e-book. They eventually arrived at three titles. After much debate they decided to choose "Digitizing ELT" as the title for their e-book.

Instructor's field notes, week 2.

Students took their roles seriously, as researchers, designers, writers and proofreaders. The authentic experience had helped them to develop new skills. 
In fact my role was effective in all stages of the e-book design project. At the beginning I contributed in the process of brainstorming and planning the project. I provided some suggestions to my group. Also, I suggested some ideas related to the layout. Moreover my biggest role was carrying the responsibility of my chapter, "PD", looking for suitable applications. I designed the log of the e-book, too.

- $\quad$ Student \# 1, discussing her roles in the e-book project.

Actually the scope of my knowledge in relation to technology has expanded. It was an authentic learning experience.

- $\quad$ Student \# 11, discussing her rewarding e-book experience.

Students showed deep involvement and passion for the project. Project ownership and accountability were important to them. The project has a manager whose responsibility was to plan and make sure that the project tasks were divided equally and that the progress of the project was monitored. The project manager was also responsible for identifying the e-book publisher and the technology needed for compiling the chapters.

I have many roles: 1) collecting the chapters. 2) organizing the chapters. 3) proofreading and editing. 4) designing and transferring files into e-book, and 5) communicating with all members and dividing work amongst them.

- $\quad$ Student \# 6, discussing his role as the e-book project manager.

2) Shared responsibilities and teamwork

Students attributed the success of the e-book project to their collaborative group work. Students were able to share their expertise as they worked collaboratively, and they reported new teamwork 
skills, a typical outcome of Project Based Learning (PBL) (Harland, 2003). PBL also allows students to tackle more complex problems than they would be capable of achieving on their own.

I can describe the experience as a massive achievement when it seeks its way to publication because the e-book is based on a consensus of more than ten people who have to come to an agreement on a number of things.

- $\quad$ Student \# 4, e-portfolio reflection.

The most valuable part in the e-book designing when we searched apps since we have to search and explore many apps. Then we have to check the rank for these apps to help us choose the best apps or the most useful one.

- $\quad$ Student \# 8, discussing lessons learned.

I have gained a number of skills among which are teamwork skills, research skills and writing skills

- $\quad$ Student \# 4, discussing lessons learned.

Beside teamwork, research and writing skills, students also reported that they had acquired 21 st century skills.

By doing the e-book project I learned many interesting things. The project was engaging and student centered, therefore many 21st century skills I acquired during its design. For instance, creativity as we were thinking together to look for a creative way to design our e-book. Communication skills, was another as we were discussing and sharing ideas inside and outside the classroom. Collaboration is another skill I gained. From the beginning we committed ourselves to work as a group and to cooperate together. Problem-solving skills also were obtained as we find some difficulties and tried to solve them.

- $\quad$ Sudent \# 1, discussing lessons learned. 
Students learned to deal with their differences and learned to respect each other, thus, sharpening their communication skills.

We need time and effort to publish a very useful e-book. There are different opinions from all members, but agreements and justifications make it go smoothly.

- $\quad$ Student \# 5, discussing lessons learned.

Communication is essential among the team members and we should be open to other ideas. Creativity can be developed through such projects.

- $\quad$ Student \# 6, discussing lessons learned.

3) Motivation and lifelong learning

Involvement in the e-book project as an authentic assessment helped students to develop self-confidence and enforced their belief that they can learn something new and that the learning experience is transferable to new situations. The project manager (Student \# 6) had already planned to share his expertise by offering e-book publishing workshops to others. Having published an e-book about the new technology applications is an achievement and testing the apps helped them to feel motivated to learn more about e-book technology and to use their new skills in their own contexts. They have shown confidence that they can publish an e-book on their own and even guide others to publish their e-books.

I plan to publish my students' work like their writings or their experiences with some learning strategies in e-books so it will be more meaningful for them to work with a sense of enjoyment.

- $\quad$ Student \# 9, discussing future plans.

Maybe my students and I can make our own e-book in which students can write articles or even stories. This can promote students' learning autonomy.

- $\quad$ Student \# 7, discussing future plans. 
I honestly liked the idea of making e-book and I think by the end of this semester, I will be able to create my own e-book whenever needed.

- $\quad$ Student \# 3, discussing future plans.

Besides acquiring the skills to design and publish an e-book, the students were excited to share their e-book with other teachers and the rest of the world.

I can suggest the e-book for the English teachers in my school and send it through WhatsApp groups and other media channels. In fact, the e-book project trained me to design any e-book which can be useful to students or teachers. So I can design my own now easily. The process of the design itself is useful as it organizes the work and I just need to follow the steps.

- $\quad$ Student \# 1, discussing future plans.

At the end, I was so happy to go through this journey and I promised myself that this experience will be only a start to create more e-books in order to share my experiences with the world.

- $\quad$ Student \# 9, e-portfolio reflection.

This finding concurred with a study conducted by Mintah (2009) who investigated physical education teachers' perceptions regarding the impact of authentic assessment on students' self-concept, motivation, and skills achievement. The study found that authentic assessment positively enhanced students' motivation. Lombardi (2008) asserted that authentic assessment could encourage students to discover things about themselves and the world around them that they did not know before.

\section{4) Promoting student behavior}

Students conveyed their enjoyment of being engaged in the authentic assessment to their friends thereby encouraging them to take the same course. One of the students said that because of the 
positive experience she had with the authentic assessment course, she recommended her friends to take the same subject with the same instructor:

I highly recommended this course to friends because it is a unique experience.

During this course, we experienced new ways of learning like learner-centered approach, experiencing new technological learning; writing an e-book, keeping e-portfolio and experimenting the recent trends in instructional learning

.- $\quad$ Student \# 9, reflecting on the experience.

Another student commented on the usefulness of the course which afforded him numerous resources to integrate technology and therefore, he would recommend the course to others.

The course is definitely among the most important courses I took during my coursework of M. Ed. I got to learn about a very useful educational technological platform which is 'padlet' through which an endless number of sources are available to anybody interested in incorporating technology into teaching and learning. Moreover, I think the course is vital for any M. Ed. student because the way it's run, triggers thinking and reflection of a high level which unfortunately undergraduate courses hardly touch on! Therefore, I truly recommend the course to others because it enables the students to create a whole e-portfolio, create a researched instructional design project, and write an e-book chapter.

- $\quad$ Student \# 4, reflecting on the experience.

This confirms the study conducted by James and Casidy (2018). The study investigated the relationship between authentic assessment and student probability of promoting the subject of study to others through positive word-of-mouth. The study revealed that the students recommended the subjects with authentic assessment to their friends 
because they believed that these subjects were important to their professional context.

\section{5) Productivity of Instructors}

One important element that this study has shown is that designing authentic assessments requires instructors to be more productive. In this study, authentic assessment required us to be involved with the students' learning process. Therefore, the researchers were involved in the process of thinking, searching for ideas, and trying new ways to make student learning more relevant by connecting experiences and knowledge gained in the classroom with the real world. For example, one student commented that they needed more guidance on how to create the e-book.

We need to be provided with more comprehensive guidelines for the project on what to do exactly and how to do it the right way.

- $\quad$ Student \# 10, commenting on a class session.

This made the researchers reflect, conduct research, and do extra reading. As a result, the researchers joined a Massive Open Online Course (MOOC) on designing e-books so that the researchers themselves could go through an experience that the researchers themselves wanted their students to undergo. The knowledge and skills gained from the course, allowed the researchers to write clear guidelines to help the students further on how to design their e-book. This is in line with the guidelines proposed by Murphy, Fox, Freeman and Hughes (2017) confirming the need for instructors to give clear guidelines and have sound knowledge and understanding of the different steps involved in authentic assessment.

Another student commented in one of the class sessions that they "need to learn about different technologies which can allow them to exchange knowledge." Therefore, the researchers created a WhatsApp group and a Padlet to allow the students to share and exchange materials and resources related to technology integration that could also help them in designing their e-book at the same time. Not only did the WhatsApp group allow the students to share resources, the researchers, also shared materials that the students 
found useful and guided them on how to use it. In addition, WhatsApp enabled the researchers to attend to the students' needs and queries.

Our course Whatsapp group provided me with important stuff in chunks to learn from, either videos, pictures or websites, and I learn the contents at my own pace... and to be close to the instructors when we needed help .

- $\quad$ Student \# 9, e-portfolio reflection.

This confirmed the findings of Holliday et al. (2015) and Azim and Khan (2012) who through authentic assessments learned more about the teaching and learning process in looking for best ways to improve students' learning. The researchers also played the role of facilitators where they employed different strategies to support the learning of the students to promote their autonomy and self-learning. The researchers also established norms and guidelines for the design of this e-book. Therefore the researchers had to read everything that the students had written to make sure that they were following the general guidelines. Therefore, reading the students' reflections and WhatsApp questions and comments allowed the researchers to understand their students' needs and enabled them to provide their students with relevant resources and advice to enhance learning and in the way they design their e-book.

\section{CONCLUSION AND RECOMMENDATIONS}

The present study highlighted the importance of authentic assessment to support students' learning. Authentic assessment is an effective measure of intellectual achievement or ability because it requires students to demonstrate their in-depth understanding, higher-order thinking, and complex problem-solving through the performance of exemplary tasks (Koh, 2017). In this study, students were engaged in an e-book design and development process as an assignment that was completed in a large collaborative group. From a social learning perspective, this authentic assessment experience required the students to collaborate. This collaboration allowed them to learn about learning how to design the e-book from their peers and instructors. The social aspect of the collaboration provided them with opportunities to ask questions and receive feedback from their 
instructors and peers so as to improve on the development of their e-book. In addition, the social constructivist learning environment of the authentic assessment made the students active, taking full credit for planning, designing and publishing the e-book. They were also engaged in higher-order thinking, solving problems and thinking creatively. This social engagement in the e-book project had empowered them to become autonomous, self-directed (English \& Kitsantas, 2013) and lifelong learners (Darma et al., 2018). The relevance of authentic assessment has also boosted their confidence to recommend the subject to their friends. Besides the students, the instructors played a key role during the authentic assessment. They not only acted as assessors, but they also facilitated the process of learning by helping students to successfully complete the assigned real world task (Azim \& Khan, 2012).

This study engaged a SoTL journey to examine the social constructivist approach to teaching and assessment. The researchers always believed that students can learn better in an experiential learning environment where they are given choices and that their voices are heard. They are expected to be independent learners with autonomy to develop their inquiry and solve problems through project based learning (Goodman, 2010). Students seemed to have gained some of the benefits of project based learning posited by Goodman (2010) such as problem-solving, critical thinking, reflection, collaboration, working independently, taking responsibility and designing the process to reach a solution. The students' experience has been compared to a journey of self-discovery and self-development.

SoTL inquiries can enhance awareness of what is taught and how teaching occurs that can lead to modifications on instructional practices, approaches to assessment and changes to the design of courses (Cox, Huber, \& Hutchings, 2004). The researchers' involvement with SoTL in this study had resulted in an increased collaboration with the students and in giving them a more meaningful experience in return. To implement learner-centered teaching requires tremendous support and letting go of class control. The researchers had to make sure that the students were ready to be independent and autonomous learners. The students were uncertain of their roles on occasions, and as instructors, the researchers had to support and provide guidance to enable them to move forward. Most of the time, the researchers stepped back and supported their independence. 
Teamwork and shared responsibilities were central to the success of this e-book project. The researchers had made it clear that the students were to be responsible for the project while the researchers monitored their progress. The researchers had also given the students autonomy to work together and to collaborate to see to the completion of the e-book. The experience of being engaged in the authentic project as an assignment left the students with a genuine sense of achievement.

Overall, the researchers learned a lot throughout the e-book project experience. When project based learning is constructed around social constructivism, it can engage students in a wealth of learning experiences and through which they can sharpen their technology skills along with 21 st century skills. In addition, students should be given the responsibility to manage and to self-regulate. Further, collaboration among students is highly practised and enriched in such environments. Students can also self-assess and self-edit their work before submission which is a highly required skill. Design thinking, critical thinking skills and creativity can also be fostered in such projects and it can clearly be seen in designing the layout of an e-book, negotiating the cover page and the contents with other students and the instructor and in evaluating the project. Finally, having computer skills in this project is crucial. One of the limitations of this study is that the findings are not generalizable. It is confined to the situation and context of the course studied. Further research is needed to show how authentic learning experiences can benefit students and enhance their level of technology integration achievement.

\section{ACKNOWLEDGEMENT}

This research received no specific grant from any funding agency in the public, commercial, or not-for profit sectors.

\section{REFERENCES}

Azim, S., \& Khan, M. (2012). Authentic assessment: An instructional tool to enhance students learning. Academic Research International, 2(3), 314-320. 
Boud, D., \& Soler, R. (2016). Sustainable assessment revisited. Assessment \& Evaluation in Higher Education, 41(3), 400413.

Boyer, E. (1990). Scholarship reconsidered: Priorities of the professoriate. Princeton, N.J: The Carnegie Foundation for the Advancement of Teaching.

Brown, T. (2008). Design Thinking. Harvard Business Review. $84-95$.

Campbell, R., Robinson, W., Neelands, J., Hewston, R., \& Massoli, L. (2007) Personalised learning: Ambiguities in theory and practice, British Journal of Educational Studies, 55(2), 135154.

Case, R. (2015). Intellectual development: Birth to adulthood. Orlando, FL: Academic Press.

Caufield, J., \& Woods, T. (2013). Experiential learning: Exploring its long-term impact on socially responsible behavior. Journal of Scholarship of Teaching and Learning, 13(2), 31-48. Retrieved from http://files.eric.ed.gov/fulltext/ EJ1011680. pdf

Crocker, A. (2013). Authentic assessment: Evaluating "real-life" applications of knowledge in higher education. Reflections. The Teaching Support Centre, Western University (Online). Retrieved from http://www. uwo. ca/tsc/resources/pdf/ Reflections_69.pdf.

Cox, R., Huber, M., \& Hutchings, P. (2004). Survey of CASTL Scholars. Stanford, CA: The Carnegie Foundation for the Advancement of Teaching.

Darma, K., Candiasa, M., Sadia, W., \& Dantes, N. (2018.) Problembased learning and authentic assessment on conceptual understanding and ability to solve mathematical problems. International Research Journal of Engineering, IT and Scientific Research (IRJEIS), 4(4), 7-16.

English, M., \& Kitsantas, A. (2013). Supporting student selfregulated learning in problem-and project-based learning. Interdisciplinary Journal of Problem-Based Learning, 7(2), 127-150.

Estepp, C., Roberts, T., \& Carter, H. (2012). An experiential learning model of faculty development to improve teaching. NACTA Journal, 56(1), 79-86. Retrieved from http://www. nactateachers.org/vol-56-num-1-mar-2012/1928 
Fauzi, S. H. M., \& Hussain, R. M. R. (2016). Designing instruction for active and reflective learners in the flipped classroom. Malaysian Journal of Learning and Instruction, 13(2), 147173.

Foo, S., \& Hussain, R. M. R. (2010). Self-directed learning in a socio constructivist learning environment. Procedia Social and Behavioral Sciences, 9(2010), 1913-1917. Doi:10.1016/j. sbspro.2010.12.423

Frey, B., Schmitt, V., Allen \& P. (2012). Defining authentic classroom assessment. Practical Assessment, Research \& Evaluation, 17(2), 1-17.

Gallagher, A., \& Thordarson, K. (2018). Design Thinking for School Leaders. Retrieved from http://www.ascd.org/publications/ books/118022/chapters/DesignInspired_Leadership. aspx?utm_source=marketing\&utm_medium $=$ email\&utm_ content=book\&utm_campaign=designthinkingemail-052918

Glover, I., Hepplestone, S., Parkin, H. J., Rodger, H., \& Irwin, B. (2016). Pedagogy first: Realising technology enhanced learning by focusing on teaching practice. British Journal of Educational Technology, 47(5), 993-1002.

Goodman, B. (2010). Project-based learning. Educational psychology, 1-8. Retrieved from www.fsmilitary.org/pdf/ Project_Based_Learning.pdf

Hadwin, A. (2008). Self-regulated learning. In T. L. Good (Ed.), 21st century education: A reference handbook (pp. 175-183). Thousand Oaks, CA: Sage.

Harland, T. (2003). Vygotsky's zone of proximal development and problem-based learning: Linking a theoretical concept with practice through action research. Teaching in Higher Education, 8(2), 263-272.

Hiemstra, R. (2006). Is the internet changing self-directed learning? Rural users provide some answer. International Journal of Self-directed Learning, 3(2), 45-59.

Holliday, W., Dance, B., Davis, E., Fagerheim, B., Hedrich, A., Lundstrom, K. \& Martin, P. (2015). An information literacy snapshot: Authentic assessment across the curriculum. 2015 76(2), 170-187.

Hutchings, P. (Ed). (2002). Ethics of Inquiry: Issues in the Scholarship of Teaching and Learning. Menlo Park, CA: The Carnegie Foundation for the Advancement of Teaching. 
James, L., \& Casidy, R. (2018). Authentic assessment in business education: Its effects on student satisfaction and promoting behaviour. Studies in Higher Education, 43(3), 401-415.

Kinay, I. \& Bagceci, B. (2016). The investigation of the effects of authentic assessment approach on prospective teachers' problem-solving skills. International Education Studies, 9(8), 51.

Koehler, M. \& Mishra, P. (2009). What is Technological Pedagogical Content Knowledge (TPACK)? Contemporary Issues in Technology and Teacher Education, 9(1), 60-70.

Koh, K. (2017). Authentic assessment. Oxford Research Encyclopedia of Education. New York: Oxford University Press. Doi.org/10.1093/acrefore/9780190264093.013.22

Kolb, A., \& Kolb, D. (2005). Learning styles and learning spaces: Enhancing experiential learning in higher education. Academy of Management Learning Education, 4(2), 193-212.

Lombardi, M. (2008). Making the grade: The role of assessment in authentic learning. Educause Learning Initiative, 1, 1-16.

McCarthy, M. (2010). Experiential learning theory: From theory to practice. Journal of Business \& Economics Research, 8(5), 131-139. doi:10.19030/jber.v8i5.725

Merriam, S. (2009). Qualitative research: A guide to design and implementation. San Francisco. CA: Jossey-Bass.

Mintah, J. (2003). Authentic assessment in physical education: Prevalence of use and perceived impact on students' selfconcept, motivation, and skill achievement. Measurement in Physical Education and Exercise Science, 7(3), 161-174.

Mueller, J. (2011). Authentic assessment toolbox. North Central College, Naperville, IL. Retrieved from http://jfmueller. faculty.noctrl.edu/toolbox/

Murphy, V., Fox, J., Freeman, S., \& Hughes, N. (2017). "Keeping it Real": A review of the benefits, challenges and steps towards implementing authentic assessment. AISHE-J, 9(3), 323132313.

Neuman, W. (2011). Social research methods: Qualitative and Quantitative Approaches (7th ed.). Boston: Pearson Education, Inc.

Oliver, B. (2015). Redefining graduate employability and workintegrated learning: Proposals for effective higher education in disrupted economies. Teaching and Learning for Graduate Employability, 6(1), 56-65. 
Patton, K., Parker, M., \& Neutzling, M. (2012). Tennis shoes required: The role of the facilitator in professional development. Research Quarterly for Exercise and Support, 83(4), 522-532. doi:10.1080/02701367

Perrin, J. (2014). Features of engaging and empowering experiential learning programs for college students. Journal of University Teaching \& Learning Practice, 11(2), 1-11.

Puentendura, R. (2010). SAMR and TPCK: Intro to advanced practice. Retrieved from http://hippasus.com/resources/ sweden2010/SAMR_TPCK_IntroToAdvancedPractice.pdf

Ponton, M., Carr, P., \& Confessore, G. (2000). Learning conation: A psychological perspective of personal initiative and resourcefulness. In H.B. Long \& Associates (Eds.), Practice and theory in self-directed learning (pp. 65-82). Schaumburg, IL: Motorola University Press.

Robertson, J. (2011). The educational affordances of blogs for self-directed learning. Computers and Education, 57(2011), 1628-1644.

Sibthorp, J., Schumann, S., Gookin, J., Baynes, S., Paisley, K., \& Rathunde, K. (2011). Experiential education and lifelong learning: Examining optimal engagement in college students. Journal of Experiential Education, 33(4), 388-392.

UNSW Teaching (2018). Assessment Methods. Retrieved from https://teaching.unsw.edu.au/assessment-methods

Reid, C., \& Fitzgerald, P. (2011). Assessment and employability. London: Higher Education Academy.

Rogers, R. (2001). Reflection in higher education: A concept analysis. Innovative Higher Education, 26(1), 37-57.

Sangster-Gormley, E. (2013). How case-study research can help to explain implementation of the nurse practitioner role. Nurse Researcher, 20(4), 6-11.

Svinicki, M. (2004). Authentic assessment: Testing in reality. New Directions for Teaching and Learning, 100, 23-29.

Thuy T., \& Dall' Alba, G. (2014). Authentic Assessment for Student Learning: An ontological conceptualisation. Educational Philosophy and Theory, 46(7), 778-791.

Tout, D., Pancini, G., \& Mccormack, R. (2014). Using Mobile Peer Mentors for Student Engagement: Student Rovers in the Learning Commons. Higher Education Research \& Development, 33(3), 595-609. 
Vygotsky, L. (1978). Mind in Society. Cambridge: Harvard University Press.

Webb, A., Moallem, M. (2016). Feed-forward for promoting problembased learning in online problem learning environments. Malaysian Journal of Learning and Instructions, 13(2), 1-41.

Young, M. (1995). Instructional design for situated learning. Educational Technology Research and Development, 41(1), 89-96.

Zaibon, S. B., \& Shiratuddin, M. (2010). Mobile game-based (MGBL): Application development and heuristic evaluation strategy. Malaysian Journal of Learning and Instructions, 7, 3-73.

Zubizarreta, J. (2009). The Learning Portfolio: Reflective Practice for Improving Student Learning (2nd ed.). San Francisco, CA: Jossey-Bass Print. 